\title{
Race, Federalism, and Voting Rights
}

\author{
Guy-Uriel E. Charles \& Luis Fuentes-Rohwer ${ }^{\dagger}$
}

\section{INTRODUCTION}

In Shelby County v. Holder, ${ }^{1}$ the Supreme Court struck down Section 4 of the Voting Rights Act ("VRA") on the grounds that the Act violated "basic principles" of federalism and the equal sovereignty of the states. ${ }^{2}$ Though the debate over "our federalism" is a longstanding one, federalism considerations in the context of voting rights are of more recent vintage. Indeed, notwithstanding the fact that Congress enacted the VRA nearly fifty years ago, it was not until thirty years later, in Miller $v$. Johnson, ${ }^{3}$ that a majority of Justices first alluded to the "federalism costs" of the VRA. ${ }^{4}$ By 1997, in Reno v. Bossier Parish School Board, ${ }^{5}$ these costs had become "serious." And in

$\dagger$ Charles S. Rhyne Professor of Law, Senior Associate Dean for Faculty \& Research at Duke Law School; Professor of Law and Harry T. Ice Faculty Fellow at Indiana University Maurer School of Law. We would like to thank Michael Kent Curtis and Heather Gerken for their helpful comments and generous feedback, as well as participants at The University of Chicago Legal Forum 2014 symposium, "Does Election Law Serve the Electorate?" We must also thank the law faculties at the William S. Boyd School of Law, University of Nevada, Las Vegas and Wake Forest Law School, where we presented earlier drafts of this project.

$1 \quad 133$ S. Ct. 2612 (2013).

2 Id. at 2624, 2631. Section 4(b) of the VRA established a mechanism or formula for identifying the parts of the country that Congress believed engaged in the most amount of racial discrimination in voting. Pursuant to Section 4, if a jurisdiction administered a test or device for voting in 1964 and less than 50 percent of that jurisdiction's citizens were registered to vote or voted, that jurisdiction was "covered" by Section $4(\mathrm{~b}) .43$ U.S.C. $\$ 1973(b)$ (2002). If a jurisdiction is "covered" by Section 4(b), Section 5 of the VRA requires that jurisdiction to submit its laws related to voting-c-"voting qualification or prerequisite to voting, or standard, practice, or procedure"-to the Attorney General of the United States or the United States District Court for the District of Columbia before those laws can go into effect. 43 U.S.C. $§ 1973(c)$ (2000).

3515 U.S. 900 (1995).

4 Id. at 926-27 ("But our belief in Katzenbach that the federalism costs exacted by $\S 5$ preclearance could be justified by those extraordinary circumstances does not mean they can be justified in the circumstances of this litigation.").

5520 U.S. 471 (1997). 
1999, in Lopez $v$. Monterey County, ${ }^{7}$ they had become "substantial."8 After the Court decided Northwest Austin v. Holder, ${ }^{9}$ in 2009, it was clear that the Court's worry about federalism costs would weigh significantly in the Court's assessment of the constitutionality of the Act. Northwest Austin echoed the Court's previous assertions that the Act imposed substantial federalism costs and implicitly warned that at some point those costs would become insurmountable. ${ }^{10}$ Scarcely four years later, in Shelby County, the Court finally concluded that the Act's federalism costs outweighed its benefits. The Court held that the Act's coverage provision, Section 4, was unconstitutional, which consequently froze the parasitic preclearance provision, Section $5 .{ }^{11}$ As a result, Northwest Austin and Shelby County have thrust federalism into the heart of voting rights disputes. ${ }^{12}$

The interjection of federalism concerns into the voting rights context raises a number of issues, three of which we examine in this Essay. First, while the Court has clearly expressed its concerns that the VRA raises constitutional questions because of its federalism costs, the Court has said very little about the content of its concerns. What exactly are these federalism costs and why have they undermined the constitutionality of the VRA? As we show in Part I, the justices who are concerned about the federalism costs of the VRA have been very vague about the object of their concerns and they have failed to provide guidance on how to balance these costs against the purported benefits of the VRA. Building on our previous work, ${ }^{13}$ we argue that the term "federalism costs" is but a truism

${ }^{6} I d$. at 480 (1997) ("To require a jurisdiction to litigate whether its proposed redistricting plan also has a dilutive 'result' before it can implement that plan-even if the Attorney General bears the burden of proving that 'result'-is to increase further the serious federalism costs already implicated by $\S 5$.”).

7525 U.S. 266 (1999).

8 Id. at 282 ("We have recognized that the Act, which authorizes federal intrusion into sensitive areas of state and local policymaking, imposes substantial federalism costs.").

9557 U.S. $193(2009)$.

10 See id. at 202.

$11133 \mathrm{~S}$. Ct. at 2631.

12 See generally Franita Tolson, Reinventing Sovereignty?: Federalism as a Constraint on the Voting Rights Act, 65 VAND. L. REV. 1195 (2012) (advocating for the abandonment of federalism as the defining norm in the voting rights context).

13 Guy-Uriel E. Charles \& Luis Fuentes-Rohwer, State's Rights, Last Rites, and 
signaling that the Voting Rights Act raises serious constitutional questions. In other words, the term is a reflection of the Court's intuitive discomfort with the exercise of federal power in a particular context or with the substantive aim of federal power in a particular context. When the Court raises the federalism costs argument, it is not clear whether it means to say anything other than simply "there is something about this that makes us deeply uncomfortable."

Second, should the Reconstruction Amendments play any role in determining the allocation of power between the federal government and the states in the context of race and voting? Or put a different way, Part II asks whether the Court in Shelby County should have considered whether Reconstruction tipped the scales on the question of our federalism. At the risk of stating the obvious, we did have a civil war, soon followed by what is known as Congressional Reconstruction. This is the time in our history that brought us myriad constitutional amendments and congressional legislation designed to alleviate the plight of the newly freed Black population. ${ }^{14}$ How should we understand this important time in our constitutional history? In specific reference to the right to vote, how should we understand the Fifteenth Amendment, and particularly its Section 2, which confers on Congress the power to enforce the Amendment "by appropriate legislation"? Or put more generally, did Reconstruction change anything? In Shelby County, Chief Justice Roberts supported his federalism argument by citing to the Tenth Amendment. ${ }^{15}$ But relying on the Tenth Amendment is too facile; the argument assumes uncritically that the Reconstruction Amendments did not alter the federalism calculus. ${ }^{16}$ Maybe at the end of the day, that argument is right and Reconstruction did not alter the original allocation of power

Voting Rights, 47 CONN. L. REV. 481, 514-24 (2014).

${ }^{14}$ See, e.g., U.S. CONST. amend. XIII-XV ("Reconstruction Amendments"); Civil Rights Act of 1866, ch. 31, 14 Stat 27; Reconstruction Act of 1867, ch. 152, 14 Stat. 428; Anti-Peonage Act of 1867, ch. 188, 14. Stat. 546; Enforcement Act of 1870, ch. 116, 16 Stat. 140; Enforcement (Ku Klux Klan) Act of 1871, ch. 22, 17 Stat. 13 (precursor to $\S 1983$ ); and, inter alia, Civil Rights Act of 1875, ch. 114, 18 Stat. 335.

15133 S. Ct. at 2623.

16 See New York v. United States, 505 U.S. 144, 207 n. 3 (White, J., dissenting) ("I do not -read the majority's many invocations of history to be anything other than elaborate window dressing.... One would not know from reading the majority's account, for instance, that the nature of federal-state relations changed fundamentally after the Civil War."). 
between the national government and the states. But the question is worth asking, particularly in this context. The Court never engages in the inquiry and its refusal to ask is the sum of our complaint.

Third, we introduce in Part III a different variable for consideration in the federalism debate. This Part asks whether the federalism project ought to demonstrate the capacity to protect the rights of racial minorities before we assent to its demands. Consider in this vein the account of federalism that lies at the heart of the modern debate over voting rights, one that we adopt for this Article. This account of federalism argues that competition between the states and the national government as sovereign sites for decision-making protects individual rights through the mechanism of self-rule. ${ }^{17}$ More specifically, according to Larry Kramer, the federalism balance forged at the founding "was also said to protect liberty, because state governments are smaller and closer to the people, hence more democratic and constitutive of popular self-government." 18 This is an argument that reconciles federalism with democracy or individual liberty. ${ }^{19}$ This understanding of federalism tips the scales against national power and in favor of local control.

If this justification for federalism is sound, it raises two related inquiries in the voting rights context. The first inquiry is whether federalism in this context works for the protection of America's quintessential minority, racial minorities. Squarely,

17 See David L. Shapiro, Federalism: A Dialogue 92-94 (1995); Kathleen M. Sullivan, From States' Rights Blues to Blue States' Rights: Federalism After the Rehnquist Court, 75 FORDHAM L. REV. 799, 809 (2006) ("[]t is immoral to cede selfgovernment to a distant bureaucrat in a remote capital rather than engaging in selfgovernment alongside nearby neighbors. This position implies a default rule in favor of local power and requires very strong justifications for federal intervention.").

18 Larry Kramer, Understanding Federalism, 47 VAND. L. REV. 1485, 1498 (1994).

19 Consider the following description by Professor Blumstein:

Federalism provides a vehicle for allowing geographically defined constituencies, especially geographically defined minorities, to have a measure of self-rule within the political framework of a broader nation-state. Federalism responds to very real majoritarian tensions in pluralistic societies. It serves as a tool for assuring limited self-government to a geographicallybased minority group. It is an accommodation to such a group whose political interests might be persistently submerged if all political decisions were to be made at the national level using the model of a unitary nation-state.

James F. Blumstein, Federalism and Civil Rights: Complementary and Competing Paradigms, 47 VAND. L. REV. 1251, 1260 (1994); see also Michael W. McConnell, Federalism: Evaluating the Founders'Design, 54 U. CHI. L. REv. 1484, 1500-07 (1987). 
the question here is whether and to what extent federalism safeguards the liberty interests of racial minorities by facilitating their ability to engage in self-rule. Facilitating the ability of racial minorities, specifically African Americans, to engage in self-rule was arguably the aim of the Reconstruction project. If "[f]ederalism is a system that permits minorities to rule,"20 we must ask, what about people of color? Does federalism permit them to rule? The challenge for Chief Justice Roberts in Shelby County is that if the federalism argument is to be taken seriously, it must be the case that the states are more likely than the federal government to provide a friendlier forum for protecting the voting rights of racial minorities. The recent history of North Carolina, ${ }^{21}$ Indiana, ${ }^{22}$ Wisconsin, ${ }^{23}$ and Texas, ${ }^{24}$ to name a few states, does not bode well for the federalism argument. Not only is there scant evidence that the states are interested in protecting the rights of voters of color, but the early returns run in the opposite direction. ${ }^{25}$ In order to justify the extension of federalism in the racial discrimination context and to render it consistent with an important consideration of federalism as self-rule, the Court must encourage the states to take up the role that federalism envisions for them, or else the Court must recalibrate the federalism line in favor of the federal

20 Heather K. Gerken, Federalism All the Way Down, 124 HARV. L. Rev. 4, 6 (2009).

${ }^{21}$ See Ari Berman, North Carolina Passes the Country's Worst Voter Suppression Law, The NATION (July 26, 2013, 9:51 AM), available at http://www.thenation.com/ blog/175441/north-carolina-passes-countrys-worst-voter-suppression-law, archived at http://perma.cc/N4NB-6RGA. For a history, see Michael Kent Curtis, Race as a Tool in the Struggle for Political Mastery: North Carolina's "Redemption" Revisited 1870-1905 and 2011-2013, 33 LAW \& INEQ. 53 (2015).

${ }^{22}$ See Crawford v. Marion Cnty. Election Board, 553 U.S. 181 (2008).

23 See Ari Berman, Voter Suppression Backfires in Texas and Wisconsin, THE NATiON (Oct. 10, 2014, 9:50 AM), available at http://www.thenation.com/blog/181942/ voter-suppression-backfires-texas-and-wisconsin, archived at http://perma.cc/DY4CD3AE.

24 See id.

25 This is in line with the conventional wisdom that federalism has been a "disaster" for racial minorities. Ilya Somin, Taking Dissenting by Deciding All the Way Down, 48 Tulsa L. Rev. 523, 530 (2013); see William H. Riker, Federalism: Origin, Operation, SIGNIFICANCE 152, 155 (1964) ("The main beneficiary [of federalism] throughout American history has been the Southern Whites, who have been given the freedom to oppress Negroes .... [I] $f$ in the United States one approves of Southern white racists, then one should approve of American federalism."). For a reevaluation of this conventional wisdom, see Heather K. Gerken, A New Progressive Federalism, 24 DEMOCRACY J. 37, 37-38 (2012), available at http://www.democracyjournal.org/24/a-newprogressive-federalism.php?page=1, archived at http: /perma.cc/B54C-Q4MN; Somin, supra, at $530-32$. 
government once again. Or put a different way, the Court must take seriously the tension between the Founding and the Reconstruction Era.

The second inquiry is related to the first. It asks whether the Court's version of decentralization will do a better job of facilitating self-rule by racial minorities than Congress's version of decentralization through the Voting Rights Act. Here is one fact about the VRA that the Court in both Northwest Austin and Shelby County failed to appreciate. To the extent that decentralization, devolution, and subsidiarity are important components of federalism, the VRA is model legislation. The VRA facilitates the devolution of power from national majorities to subnational majorities and from subnational majorities to sub-state minorities. To be sure, in the context of the VRA, these minorities happen to be racial minorities. But they are minorities nonetheless, racial groups who are exercising consequential political power, thanks to the VRA, at the state and sub-state levels. This is an instance where nationalism facilitates the values of federalism. Thus the question at the heart of the larger debate: can the states do better? Can federalism do better? If federalism cannot do better to facilitate the political power of racial minorities at the sub-national level, then federalism will not do. And if so, then there is no compelling argument for enforcing federalism over nationalism in the voting context.

\section{JUSTICE BLACK'S VINDICATION}

The term "federalism costs" has become an empty slogan or, at best, a truism in voting rights law, and particularly in reference to the Voting Rights Act. The justices who worry about the federalism costs of the VRA-for ease of exposition we will term them the anti-nationalists-remind us often that the Act imposes "federalism costs." At the heart of this critique stands the figure of Justice Black, the sole dissenter in the canonical South Carolina $v$. Katzenbach, ${ }^{26}$ which first considered the constitutionality of the VRA. Justice Black complained that Section 5 "approaches dangerously near to wiping the States out as useful and effective units in the government of our country." 27

\footnotetext{
26383 U.S. 301 (1966).

27 Id. at 360 (Black, J., dissenting).
} 
Our task in this Part is to contextualize the Court's concern over federalism costs in Northwest Austin and Shelby County.

A. Origins

Consider first the origin of the concept. The Court first mentioned these "federalism costs" in Miller $v$. Johnson. ${ }^{28}$ In Miller, an opinion authored by Justice Kennedy, the Court struck down Georgia's Congressional redistricting plan on the ground that it was a racial gerrymander in violation of the Fourteenth Amendment. ${ }^{29}$ Miller is notable as the first case to give substance to the Court's Shaw doctrine. In Shaw v. Reno, ${ }^{30}$ the Court first concluded that race-conscious and bizarrelyshaped districts could be unconstitutional under the Fourteenth Amendment on the ground that these districts communicated an "expressive harm" ${ }^{31}$ about the relationship between race and political identity. ${ }^{32}$ Miller replaced Shaw's eccentric and amorphous "expressive harms inquiry," which focused on the messages sent by the use of race in the creation of districting plans, with a predominant factor inquiry, which focused on whether race was the predominant factor in the redistricting process. ${ }^{33}$ Under this new test, state actors may not use race for its own sake as the "dominant and controlling rationale in drawing its district lines." ${ }^{34}$ When they do, the Court will apply strict scrutiny.

In addressing whether Georgia had a compelling state interest for using race, the Court argued that the State's "true interest in designing" the district was "to satisfy the Justice Department's preclearance demands." 35 The Court stated that jurisdictions covered by Section 5 do not have a "compelling interest in complying with whatever preclearance mandates the

515 U.S. 900, 926 (1995).

${ }^{29}$ See id. at 928 .

30509 U.S. 630 (1993).

31 See Richard H. Pildes \& Richard G. Niemi, Expressive Harms, "Bizarre Districts," and Voting Rights: Evaluating Election-District Appearances After Shaw v. Reno, 92 MicH. L. REV. 483, 506-07 (1993).

${ }^{32}$ Shaw v. Reno, 509 U.S. 630, 657-58 (1993).

33 Miller, 515 U.S. at 916.

${ }^{34} \quad$ Id. at 913.

${ }^{35} \quad$ Id. at 921. 
Justice Department issues." ${ }^{36}$ Consequently, the Voting Rights Act did not require the enacted plan. ${ }^{37}$ The Court believed that the Attorney General should not have refused to preclear the first plan because there was no reason to believe that the plan violated Section 5's non-retrogression standard. ${ }^{38}$ From the Court's perspective, the Department of Justice pursued a policy of maximizing majority-minority districts and refused to preclear Georgia's plan unless Georgia created more racial districts. ${ }^{39}$ To interpret the Act in this way, according to the Miller Court, would raise "serious constitutional concerns." 40 The Court then went on to state:

In South Carolina v. Katzenbach, we upheld $\S 5$ as a necessary and constitutional response to some States' "extraordinary stratagems of contriving new rules of various kinds for the sole purpose of perpetuating voting discrimination in the face of adverse federal court decrees." But our belief in Katzenbach that the federalism costs exacted by $\S 5$ preclearance could be justified by those extraordinary circumstances does not mean they can be justified in the circumstances of this case. $^{41}$

As this discussion took place toward the very end of the opinion, the Court did not further elaborate on what it meant by federalism costs. Two years after Miller, in Reno $v$. Bossier Parish, ${ }^{42}$ the Court, in an opinion by Justice O'Connor, reversed a lower court's decision that would have permitted the Justice Department to decline to preclear a proposed redistricting plan under Section 5 of the Act on the ground that the proposed plan would dilute the voting rights of racial minorities in violation of

\footnotetext{
36 Id. at 922.

37 See Miller, 515 U.S. at 921.

38 See id. at 923. Long defined by Beer v. United States, 425 U.S. 130 (1976), nonretrogression only requires that the voting change in question does not make voters of color worse off (i.e., does not "retrogress") as compared to the status quo. Id. at 141.

39 See Miller, 515 U.S. at 924-25.

$40 \quad$ Id, at 926.

41 Id. at 926.

42520 U.S. 471 (1997).
} 
Section 2 of the Act. ${ }^{43}$ In explaining its decision, the Court concluded that:

Section 5 already imposes upon a covered jurisdiction the difficult burden of proving the absence of discriminatory purpose and effect.... To require a jurisdiction to litigate whether its proposed redistricting plan also has a dilutive "result" before it can implement that plan-even if the Attorney General bears the burden of proving that "result"-is to increase further the serious federalism costs already implicated by Section 5.44

Again, as in Miller, the majority did not expand further on the now "serious" federalism costs of the VRA. Two years after Bossier Parish, in Lopez v. Monterey County, ${ }^{45}$ the Court once again referenced the federalism costs of the VRA while deciding whether a covered county, Monterey County, in a non-covered state, California, had to preclear voting changes compelled by the non-covered state. ${ }^{46} \mathrm{~A}$ group of plaintiffs filed suit and argued that the changes were subject to preclearance under Section 5 because the county is a covered jurisdiction under Section $4{ }^{47}$ California, which had intervened in the litigation, argued that the VRA could not withstand constitutional scrutiny if it "were interpreted to apply to voting measures enacted by States that have not been designated as historical wrongdoers in the voting rights sphere." 48 The Court acknowledged that it has "recognized that the Act, which authorizes federal intrusion into sensitive areas of state and local policymaking, imposes substantial 'federalism costs." 49 However, citing one of its thenrecent cases interpreting the scope of Congress's enforcement powers under Section 5 of the Fourteenth Amendment, the Court rejected California's argument on the theory that "legislation which deters or remedies constitutional violations can fall within the sweep of Congress' enforcement power even if in the process it prohibits conduct which is not itself

\footnotetext{
43 Id. at 480 .

44 Id. at 480.

45525 U.S. 266 (1999).

46 Id. at 282 .

$47 \quad I d$. at 274.

$48 \quad I d$. at 282.

49 Lopez, 525 U.S. at 282.
} 
unconstitutional and intrudes into legislative spheres of autonomy previously reserved to the States."50

Consistent with its opinions in Miller and Bossier Parish, the Court's discussion of federalism costs in Lopez is conclusory and devoid of analysis. Moreover, the Court did not provide any argument in support of its decision that the VRA could withstand the "substantial" federalism costs in Lopez but not the serious costs in Bossier Parish. As Professor Ellen Katz wrote in the wake of Lopez and Bossier Parish, "[l]eft unexplained [in Lopez] is why the Court understood the federalism costs implicated in the Bossier Parish cases to be preclusively high, while it viewed the costs at issue in Lopez to be the necessary and justifiable result of implementing the VRA." 51

In retrospect, it should not have been surprising that in both Northwest Austin and Shelby County the Court once again referenced the "substantial federalism costs" of the Act. 52 This is true even if few scholars and voting rights experts expected the Court to strike down Section 4, and effectively suspend Section 5 , by simply chanting federalism costs. What is surprising to us is how much the Court left unsaid. That is, if the Court was going to conclude that Section 4 of the VRA is unconstitutional because of the federalism costs imposed by the Section 4-Section 5 tandem, it should have articulated those costs in explicit terms.

\section{B. Context: Slow Progression Towards Anti-Nationalism}

So what, then, are these federalism costs? The Court and scholars alike have come to think of these "federalism costs" as describing how the Act's special provisions-its coverage provision, Section 4, and its preclearance provision, Section 5supposedly intrude upon state sovereignty. ${ }^{53}$ There are a

50 Id. (quoting City of Boerne v. Flores, 521 U.S. 507, 518 (1997)) (quotations omitted).

51 Ellen D. Katz, Federalism, Preclearance, and the Rehnquist Court, 46 VILL. L. REV. 1179, 1180 (2001).

52 See Shelby Cnty. v. Holder, 133 S. Ct. 2612, 2621 (2013) ("We explained that $\S 5$ 'imposes substantial federalism costs' and 'differentiates between the States, despite our historic tradition that all the States enjoy equal sovereignty.") (quoting N.W. Austin Mun. Utility Dist. No. One v. Holder 557 U.S. 193, 202-03 (2009)); N.W. Austin, 557 U.S. at 202 ("At the same time, $\S 5$, "which authorizes federal intrusion into sensitive areas of state and local policymaking, imposes substantial "federalism costs."”').

53 See, e.g., Michael Halberstam, The Myth of "Conquered Provinces": Probing the 
number of objections to the VRA that the Court could be summarizing by the phrase "federalism costs." Certainly, at the highest level of generality, when the Court talks about the Act's federalism costs it means to say that the legislation sweeps broadly, that it unconstitutionally sets Congress as overseers of the states, that it shifts the traditional burden of proof to the submitting jurisdiction under preclearance review, and as Judge Williams stated in his dissent from the D.C. Circuit's decision in Shelby County, "[i]n the vast majority of cases, ... the overall effect of $\S 5$ is merely to delay implementation of a perfectly proper law." ${ }^{4}$ In Northwest Austin, Chief Justice Roberts framed the concern as follows:

"Section 5 goes beyond the prohibition of the Fifteenth Amendment by suspending all changes to state election law-however innocuous-until they have been precleared by federal authorities in Washington, D.C. The preclearance requirement applies broadly, and in particular to every political subdivision in a covered State, no matter how small." 55

Federalism costs is a shorthand phrase for a diffuse set of objections that essentially can be summarized by the conclusion that the VRA is "strong medicine." 56

One can get some purchase on the meaning of the phrase by examining the various federalism-based objections that a number of Justices have offered since the Court first heard a constitutional challenge to the VRA. The worry that the VRA imposes federalism costs is not new. Though a majority of the Court did not express a concern with the federalism costs of the VRA until Miller, a number of anti-nationalist justices have long expressed their concern with the VRA in federalism terms. Chief Justice Roberts could have been parroting Justice Black in South Carolina v. Katzenbach, whom Chief Justice Roberts cited in Northwest Austin.57 Justice Black objected to the VRA

Extent of the VRA's Encroachment on State and Local Autonomy, 62 HASTINGS L.J. 923 (2010) (discussing the cases and literature on the federalism costs of the VRA).

${ }_{54}$ Shelby Cnty. v. Holder, 679 F.3d 848, 886 (D.C. Cir. 2012) (Williams, J., dissenting).

55557 U.S. at 202 (emphasis in original).

56 Shelby Cnty., 133 S. Ct. at 2618.

${ }^{57}$ See N.W. Austin, 557 U.S. at 202. 
because Section 5 "so distorts our constitutional structure of government" by requiring state officials to "beg" the federal government to approve state laws. ${ }^{58}$ Justice Black argued that Section 5 was unconstitutional, as he believed that it gave the federal government the ability to veto state laws. ${ }^{59}$ The Chief Justice could have also looked to Justice Powell's dissent in Georgia v. United States, ${ }^{60}$ which held that Georgia's state legislative reapportionment plan was subject to preclearance under the VRA, and which drew a Justice Black-like dissent from Justice Powell. ${ }^{61}$ Justice Powell exclaimed that it "is indeed a serious intrusion, incompatible with the basic structure of our system, for federal authorities to compel a State to submit its legislation for advance review."62 Justice Powell saw the VRA as an "unprecedented requirement of advance review of state or local legislative acts by federal authorities."63

Chief Justice Roberts also cited Justice Harlan's criticism of the Court's broad construction of the statute in Allen $v$. State Board of Elections. ${ }^{64}$ But Justice Harlan presented a slightly different constitutional objection to the VRA. For Justice Harlan, the problem with the VRA was not that the states could not implement their law until approved by the federal government. Rather, Justice Harlan objected to the proposition that "Congress would single out a handful of States as requiring stricter federal supervision concerning their treatment of a problem that may well be just as serious in parts of the North as it is in the South."65 Racial discrimination in voting, Justice Harlan believed, was "national in scope" and therefore deserved a national, as opposed to a regional, response. ${ }^{66}$ Congress's

58 South Carolina v. Katzenbach, 383 U.S. 301, 358 (1966) (Black, J., dissenting) ("Section 5, by providing that some of the States cannot pass state laws or adopt state constitutional amendments without first being compelled to beg federal authorities to approve their policies, so distorts our constitutional structure of government as to render any distinction drawn in the Constitution between state and federal power almost meaningless.").

59 See id. at 360.

$60 \quad 411$ U.S. 526 (1973).

61 Georgia v. United States, 411 U.S. 526, 541 (1973).

62 Id. at 545 (Powell, J., dissenting) (emphasis in original).

63 Id. at $545 \& \mathrm{n} .{ }^{*}$ (Powell, J., dissenting).

64393 U.S. 544; N.W. Austin, 557 U.S. at 202.

65 Allen v. State Bd. of Elections, 393 U.S. 544, 586 \& n. 4 (1969) (Harlan, J., concurring in part and dissenting in part).

66 See id. at 586. Justice Harlan was not alone in objecting to the selective 
failure to enact national legislation for a national problem rendered the regional coverage-preclearance structure unconstitutional.

Chief Justice Roberts could also have been attempting to restate then-Justice Rehnquist's dissent from the Court's opinion in City of Rome v. United States. ${ }^{67}$ In City of Rome, the city of Rome argued that because it was a non-covered jurisdiction and it had not engaged in racial discrimination in at least seventeen years, it should not be required to preclear its voting changes, notwithstanding the fact that the city was within a covered jurisdiction, Georgia, which was required to preclear its voting changes. ${ }^{68}$ The Court disagreed and held that the preclearance requirement applied to a non-covered jurisdiction in a covered state. ${ }^{69}$ Additionally, even though the city's voting changes may not have been enacted with a discriminatory purpose, the Court concluded that the Attorney General was right to object to the voting changes because the changes had a discriminatory effect. ${ }^{70}$

The Court's analysis drew a dissent from Justice Rehnquist primarily on the ground that the Court's interpretation of the Act unconstitutionally interfered with a local jurisdiction's autonomy, because the record was clear that Rome had not engaged in intentional discrimination. Rehnquist stated that Congress did not have the power "to prohibit Rome from structuring its government in the manner as its population sees fit absent a finding or unrebutted presumption that Rome has been, or is, intentionally discriminating against its black citizens. Rome has simply committed no constitutional violations, as this Court has defined them." 71 The absence of intentional discrimination for a seventeen-year period also dictated that Congress lacked the power to interfere with the political autonomy of the local jurisdiction.

Perhaps no justice articulated the worry about local control as eloquently as Justice Powell, who also objected to the Court's

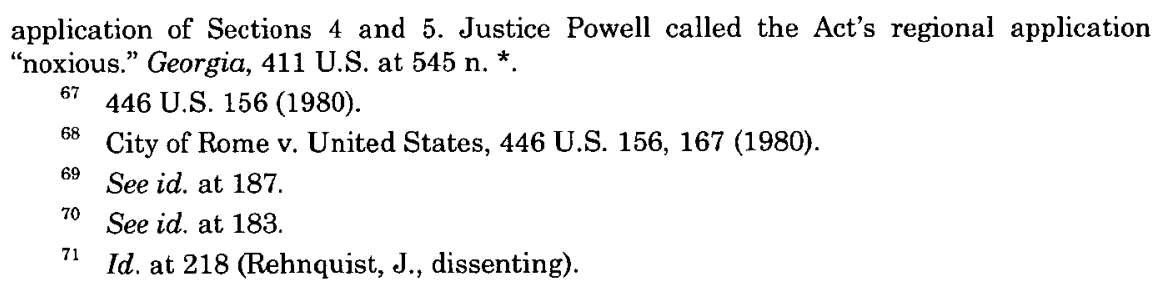


decision in City of Rome. Justice Powell argued that Section 5 encroaches on state sovereignty, which he found "especially troubling because it destroys local control of the means of selfgovernment, one of the central values of our polity." 72 From his perspective:

Unless the federal structure provides some protection for a community's ordering of its own democratic procedures, the right of each community to determine its own course within the boundaries marked by the Constitution is at risk. Preclearance also operates at an individual level to diminish the voting rights of residents of covered areas. Federal review of local voting practices reduces the influence that citizens have over policies directly affecting them, and strips locally elected officials of their autonomy to chart policy. ${ }^{73}$

Chief Justice Roberts's reference to federalism costs in Northwest Austin and Shelby County is meant to explicitly incorporate by reference all of these prior expressions of concern and subsume them under the federalism costs umbrella. ${ }^{74}$ Interestingly, it did not matter to the Court's decision in Shelby County that most of these concerns were never expressed by a majority of the Court, but only by individual justices in dissenting or concurring opinions. Moreover, as we note in Part I.A, even when the Court has articulated its concerns with the federalism costs of the VRA, as it did in Northwest Austin and Shelby County, it has done so in vague terms.

\section{Assessing the "Federalism Costs" Concern}

When the Court first expressed a concern with the federalism costs of the VRA in Miller $v$. Johnson, it was at a time that the Court's federalism revolution was in full swing, with cases such as United States v. Lopez, ${ }^{75}$ Seminole Tribe v. Florida, ${ }^{76}$ and City of Boerne $v$. Flores ${ }^{77}$ casting grave

72 City of Rome, 446 U.S. at 201 (Powell, J., dissenting).

73 Id. at 201-02 (Pọwell, J., dissenting).

74 See N.W. Austin, 557 U.S. at 202 ("These federalism costs have caused Members of this Court to express serious misgivings about the constitutionality of $\S 5$.").

75514 U.S. 549 (1995).

76517 U.S. 44 (1996). 
constitutional doubts on the exercise of Congressional power pursuant to Section 5 of the Fourteenth Amendment. To be sure, the Court was unprepared to subject the VRA to meaningful constitutional scrutiny, at least not yet. Indeed, in City of Boerne, one of the Court's new federalism cases, Justice Kennedy pointed to the VRA as a model exercise of Congressional power. ${ }^{78}$ This led at least one prominent scholar to reason that the Court's new federalism jurisprudence did not threaten the constitutionality of Section $5 .{ }^{79}$ But Miller reflected the then-ascendant federalism jurisprudence.

If City of Boerne was reflective of the Court's approach, Northwest Austin and Shelby County represent a course correction. Chief Justice Roberts's argument in Northwest Austin and Shelby County is two-fold. First, he argues that the Section 4-Section 5 coverage-preclearance tandem has always been costly. In Shelby County, ${ }^{80}$ he points us back to Northwest Austin and in Northwest Austin, he points us back to Miller $v$. Johnson. ${ }^{81}$ Miller takes us all the way back to Justice Black's dissent in Katzenbach. ${ }^{82}$ The point is that the VRA has imposed federalism costs since its inception and the Court has been cognizant of that fact. Second, he argues, though those costs have been warranted because of the pervasiveness of racial discrimination in voting, they are no longer warranted because "[t]hings have changed." 83 Racial discrimination in voting by southern state actors is no longer the national problem that it once was. Consequently, the constitutional costs of the VRA now outweigh its purported benefits.

The problem with the majority's analysis in Northwest Austin and in Shelby County is that nowhere do we get an actual account of the tangible costs imposed by the VRA. Does the VRA in fact limit local autonomy? Does it prevent localities from implementing beneficial laws? How do we in fact balance those costs against the purported benefits of the VRA? Is the

\footnotetext{
77521 U.S. 507 (1997).

78 See id. at 519 (1997).

79 See Pamela S. Karlan, Section 5 Squared: Congressional Power to Extend and Amend the Voting Rights Act, 44 Hous. L. REV. 1, 4 (2007).

80133 S. Ct. 2612, 2621 (2013).

81557 U.S. 193, 202 (2009).

82515 U.S. 900, 926-27 (1995).

83 N.W. Austin, 557 U.S. at 202.
} 
preclearance regime simply preventing wholesome electoral rules from going into effect instead of precluding discriminatory practices? Is the sixty-day moratorium that the VRA imposes on covered jurisdictions before they can implement their voting changes costly? The Court does not answer these types of questions nor does it appear interested in the requisite analysis. The Court's conclusion appears to be an ipse dixit; it is an article of faith. The VRA limits local jurisdictional autonomy, even if it does so slightly; therefore, the VRA imposes federalism costs and is presumptively unconstitutional.

Upon inspection, the federalism costs objection is overblown. ${ }^{84}$ As a point of departure, Section 5's most critical feature is that it addresses the problem of information asymmetry. Section 5's "preclearance requirement forces the institutions with the best information about potentially discriminatory practices to share that information with third parties. Preclearance thus facilitates monitoring through disclosure." 85 Preclearance is "a regime of forced disclosure or 'information-pushing." "86

A regime of "information-pushing" or compelled disclosure does not seem sufficiently problematic to raise such significant constitutional questions. In other contexts, such as campaign finance, the Court has accepted as "sufficiently important" the government's information-eliciting interest in compelling political candidates, parties, and even individuals to disclose political contributions and expenditures even in the face of countervailing First Amendment concerns. ${ }^{87}$ The Court went as far as to state in Citizens United v. FEC, the case that struck down a federal statute prohibiting corporate expenditures, that "disclosure is a less restrictive alternative to more comprehensive regulations of speech." 88 Perhaps forced disclosure is a federalism cost and the federal government

\footnotetext{
84 See Halberstam, supra note 53.

85 Guy-Uriel E. Charles \& Luis Fuentes-Rohwer, Mapping a Post-Shelby County Contingency Strategy, 123 YALE L.J. ONLINE 131, 137 (2013).

86 Halberstam, supra note 53, at 955.

87 See, e.g., Buckley v. Valeo, 421 U.S. 1, 66 (1976) (noting that "disclosure provides the electorate with information 'as to where political money comes from and how it is spent by the candidate"); see also McConnell v. FEC, 540 U.S. 93, 196 (2003); see also Doe v. Reed, 561 U.S. 186 (2010). See generally Elizabeth Garrett, McConnell v. FEC and Disclosure, 3 ELECTION L.J. 237 (2004).

88 Citizens United v. Fed. Election Comm'n, 558 U.S. 310,369 (2010).
} 
cannot compel the states to provide information about how their electoral changes impact racial minorities. If this were the case, it would have been helpful for the Court to address the point directly than to wave generally about federalism costs.

It is true that preclearance is not simply or only information-eliciting. It does preclude covered jurisdictions from changing their election laws unless federal authorities, specifically the Department of Justice or the Federal District Court for the District of Columbia, approve those laws. This is the argument for loss of control, and the point on which Justice Black focused his dissent in Katzenbach. The argument does not stand up to scrutiny. To begin, almost all of the laws submitted for preclearance are precleared, on the order of 99 percent. ${ }^{89}$ Preclearance, as a practical matter, does not prevent covered jurisdictions from implementing their electoral laws. Undoubtedly, as a prophylaxis, preclearance might preclude some jurisdictions from passing certain laws that those jurisdictions fear will not be precleared. But if most of those would-be laws would have been discriminatory, then the preclearance mechanism is performing its deterrent effect as designed. Because the preclearance rate is so high, there is no reason to believe that covered jurisdictions would hesitate to promulgate non-discriminatory laws because of the preclearance mechanism. If they promulgate a law, it will be precleared, except in the very small percentage of cases. Thus, at most, preclearance forces a dialectic exchange between national officials and local officials as local officials confer with national officials to ensure that local laws are not discriminatory. ${ }^{90}$ Practically, in almost all cases, the practice of preclearance boils

89 See Drew Spencer \& Rob Richie, The Role of Fair Voting Systems in the Shelby County Case, available at http:/www.fairvote.org/research-and-analysis/blog/the-role-offair-voting-systems-in-the-shelby-county-case/, archived at http://perma.cc/7DDWBXNR ("Preclearance is effective for stopping the most discriminatory laws from even going forward, as over $99 \%$ of DOJ reviews result in preclearance.").

${ }^{90}$ See Shelby Cnty. v. Holder, 133 S. Ct. 2612, 2639 n. 4 (2013) (Ginsburg, J., dissenting) ("Congress also received evidence that many covered jurisdictions engaged in an 'informal consultation process' with DOJ before formally submitting a proposal, so that the deterrent effect of preclearance was far broader than the formal submissions alone suggest."). For an argument that the Roberts Court no longer considers this deterrence function as a justification for the constitutionality of the preclearance regime, see Ellen D. Katz, Dismissing Deterrence, 127 HARV. L. REV. F. 248 (2014). 
down to a temporary delay of less than sixty days before the covered jurisdiction can implement its law. ${ }^{91}$

Moreover, preclearance does not take away from the states and local officials the authority to design their election systems. Professor Halberstam has observed:

State and local officials decide on voter registration qualifications, practices and procedures, what type of voting systems to adopt, how to district, where to locate polling places, and where to expand cities by annexing neighboring populations. So long as the new law, practice, or procedure does not violate the antidiscrimination standard, there is no substantive federal input. Decisions on election design remain in local hands. ${ }^{92}$

In fact, rather than take away local control, preclearance enhances localism. This is because preclearance forces state and sub-state officials to consult with local minorities to assure that their needs are taken into account in the promulgation of electoral rules and in the design of electoral institutions. From this perspective, preclearance is localizing, if local minorities count. The only national policy effectuated by preclearance is that of non-discrimination, which is a constitutional command.

Of course one could argue that national policy, even if backed by a constitutional command, nevertheless infringes upon state sovereignty. An obvious answer is that the Constitution trumps state sovereignty where state sovereignty is inconsistent with constitutional values. But this reply is too facile and does not respond to Shelby County's federalism impulse. A more complicated analysis recognizes, as the Court in Shelby County recognized, that both federalism and nondiscrimination are constitutional commands. If one is committed to that view-that federalism and non-discrimination are both constitutional commands-the next step is determining which command trumps when giving effect to both are not possible. For a long time, at least in the domain of voting, there was a clear answer: racial equality trumps federalism every time. But Shelby County muddies the waters a bit and introduces two

\footnotetext{
91 See Voting Rights Act, 79 Stat. 439, codified at 42 U.S.C. $\$ 1973 c(a)$.

92 Halberstam, supra note 53 , at 948 .
} 
possibilities. One possibility is that federalism trumps racial equality. This would be a radical and aggressive departure from current doctrine. It would also be an aggressive interpretation of Shelby County. Interpreting Shelby County in this way would erase the constitutional, statutory, and jurisprudential achievements of Reconstruction and the Civil Rights Movement, upon which all of our conceptions of racial equality rests. No serious person, no matter how committed they are to federalism, would argue today that state sovereignty trumps racial equality where the two are incapable of inhabiting the same constitutional space.

But there is a much less radical reading of the role that federalism plays in Shelby County. If the majority's goal in Shelby County is to give effect to two constitutional values that can sometimes cause earthquakes, like tectonic plates rubbing against each other, one strategy for reducing the friction is to reduce the span of one of the plates. That is, we can limit the clash between federalism and racial equality by interpreting the scope of one or the other narrowly. Arguably, this was the option that the Court chose in the early cases interpreting the VRA, in particular South Carolina v. Katzenbach, in which nationalism trumped federalism. ${ }^{93}$ This is also, arguably, the strategy that best explains Shelby County, with a crucial difference of course. Whereas Katzenbach interpreted federalism narrowly and thus minimized a clash between federalism and racial equality, Shelby County interprets racial equality narrowly to avoid a clash between federalism and racial equality. From this perspective, the "federalism costs" imposed by the VRA are costs to the federalism project itself. At stake is the conception of states as sovereign or even autonomous entities entitled to selfrule with minimal interference from the center. A broad conception of racial equality, which would justify Congressional intervention in the voting machinery of the states through the VRA, would undermine that project.

Fundamentally, then, Shelby County does not present new arguments. What we see instead is a recalibration of the age-old tension between federalism and non-discrimination. At the level of doctrine, one could argue that Shelby County is the culmination of an echo chamber, as the conservative justices 
cross-cite old opinions in an effort to legitimize the "federalism costs" narrative. Northwest Austin and Shelby County seek to communicate the impression, whether accurate or not, that the worry about federalism costs is a longstanding concern of not just a few justices, but of the Court itself. The difference between Shelby County and Katzenbach is that the nationalists are in the minority and the anti-nationalists now control the Court. Dissenting and concurring positions are now majority opinions. Judicial ideology explains the consideration for federalism and the costs to federalism, as part and parcel of a larger solicitude towards the rights of states and against a strong assertion of national power.

As we argued in this Part, however, it is difficult to determine concretely what these federalism costs are. The harder one looks, the more these federalism costs seem more hypothetical than actual. The inability to identify the substantive content of these federalism costs with any precision explains why the Court in both Northwest Austin and Shelby County opted to frame its fears about federalism costs in expressive terms, ${ }^{94}$ without any evident struggle to identify more concretely the substance of those costs. For the Court in Northwest Austin and Shelby County, in other words, it comes down to the loss of dignity by the states and the concomitant ignominy caused by the reduction of the states' sovereignty. ${ }^{95}$

The term "federalism costs" has become the boogeyman of race conscious legislation, at least in the context of voting rights. The idea of "federalism costs" is shorthand for the accepted view that the Voting Rights Act is "strong medicine" and of necessity treads on issues reserved to the states by the Constitution as drafted in 1787. The phrase is the language in which the Court signals its displeasure with how the Act has undermined the sovereignty of the states, not always or particularly in material terms, but also in expressive terms. At the end of the day, Justice Black has won.

94 See Charles \& Fuentes-Rohwer, supra note 13, at 516 (noting that the federalism worry is about the "message that the VRA sends about the proper and respective roles of the federal government and the states").

${ }^{95}$ As Professor Tolson has argued, the Court seems to confuse sovereignty with autonomy. See Tolson, supra note 12, at 1199-201, 1207. 


\section{How DID RECONSTRUCTION AFFECT OUR FEDERALISM?}

The majority's decision in South Carolina v. Katzenbach was based, at least in part, on the proposition that notwithstanding the federalism costs imposed by the VRA, the Fourteenth and Fifteenth Amendments authorized those costs. Put differently, one could easily concede the proposition that the Act is far more aggressive than most legislation, that the costs it exacts from the states are "extraordinary," 96 even unique, that the constitutional concerns are "substantial," 97 but nevertheless conclude that the Act passes rational basis review because the Reconstruction Amendments authorize Congress to limit state autonomy in the manner effected by the Act.

This is one way of understanding the Court's decision in Katzenbach. Read this way, Katzenbach stands for the proposition that a central purpose of the Reconstruction Amendments was to authorize Congress to rein in the states and limit federalism when necessary to guard against racial inequality. The key inquiry in Katzenbach, and the inquiry that should have motivated the Court in Shelby County, is not whether the Act exacts costs on state sovereignty. Rather, the question is whether the Reconstruction Amendments authorized Congress to impose these costs. Relatedly, one can also understand Katzenbach as standing for the proposition that Congress is the proper institution for deciding whether the costs imposed by the Act are justified. ${ }^{98}$ So long as Congress's decision is "reasonable" under the Constitution, the Court is compelled to defer to Congress's determination. The fundamental inquiry then is, did the Reconstruction Amendments change anything? Interestingly and surprisingly, as we discuss in this Part, this is an issue that the majority in Shelby County did not address.

We begin with first principles. Our federalism evokes images of "Fourth of July parades down Main Street, drugstore soda fountains, and family farms with tire swings in the front yard." 99 This is not to say, as the Supreme Court wrote in

96 Shelby Cnty. v. Holder, 679 F.3d 848, 884 (D.C. Cir. 2012) (Williams, J., dissenting).

${ }^{97}$ Id. at 885 (quoting N.W. Austin, 557 U.S. at 202).

98 Charles \& Fuentes-Rohwer, supra note 13, at 504-08; Luis Fuentes-Rohwer, Legislative Findings, Congressional Powers, and the Future of the Voting Rights Act, 82 IND. L.J. 99 (2007).

99 Edward L. Rubin \& Malcolm Feeley, Federalism: Some Notes on a National 
Younger $v$. Harris, ${ }^{100}$ that courts must blindly defer to the states, nor does it place control of all important policy questions in the national government.101 Rather, the Court explained that federalism is "a system in which there is sensitivity to the legitimate interests of both State and National Governments, and in which the National Government, anxious though it may be to vindicate and protect federal rights and federal interests, always endeavors to do so in ways that will not unduly interfere with the legitimate activities of the States."102 This sensitivity demands accommodation of interests. Power is centered in neither sphere but is balanced appropriately.

One question raised by Shelby County is whether the Court has properly allocated the power between the federal government and the states. Shelby County is yet another case in a notable line of cases showing that the states are winning the federalism battle. If we think of our federalism as a pendulum, ${ }^{103}$ it is clear that the weight is pivoting decidedly towards the states. For the most part, the anti-nationalists justify this swing by citing to the virtues of federalism, which include increased political participation, governmental responsiveness, and checks on governmental power. ${ }^{104}$ Above all, federalism "ensure[s] protection of our fundamental liberties." 105 It is fair to ask whether these ostensible virtues are supported empirically, ${ }^{106}$ a question to which we will return below. For the

Neurosis, 41 U.C.L.A. L. REV. 903, 906 (1994)

100401 U.S. 37 (1971).

101 See id. at 44.

102 Id.

103 See The Annual Chief Justice Earl Warren Conference, The Courts: The PENDULUM OF FEDERALISM (Joanna Dailey, ed. 1979); Ronald J. Bacigal, The Federalism Pendulum, 98 W. VA. L. REv. 771, 771 (1996); Keith Werhan, Checking Congress and Balancing Federalism: A Lesson from Separation-of-Powers Jurisprudence, 57 WASH. \& LEE L. REV. 1213, 1242-57 (2000).

104 See, e.g., Gregory v. Ashcroft, 501 U.S. 452, 457-60 (1991); Ann Althouse, Variations on a Theory of Normative Federalism: A Supreme Court Dialogue, 42 DUKE L.J. 979 (1993); Deborah J. Merritt, The Guarantee Clause and State Autonomy: Federalism for a Third Century, 88 CoLUM. L. REv. 1, 3-10 (1988).

105 United States v. Lopez, 514 U.S. 549, 552 (1995) (citation omitted). See Printz v. United States, 521 U.S. 898, 921 (1997) ("This separation of the two spheres is one of the Constitution's structural protections of liberty."); Gregory, 501 U.S. at 458 (explaining that "a healthy balance of power between the States and the Federal Government will reduce the risk of tyranny and abuse from either front").

106 See Erwin Chemerinsky, Does Federalism Advance Liberty?, 47 WAYNE L. REv. 911, 913 (2001) ("One thing, however is clear: federalism has not been about increasing liberty."); Rubin and Feely, supra note 99, at 907 ("In our view, federalism in America 
moment, we consider a prior question: whether the Reconstruction Amendments ought to matter to the antinationalist justices as they reallocate the federalism balance. That is, did the Reconstruction Amendments alter the federalism calculus at all and should anti-nationalist judges care? Irrespective of what historians of Reconstruction tell us about this question, how do the justices themselves understand the question, and how do they address it?

Return once more to the Court's Shelby County opinion. This case is tailor-made for a discussion of congressional powers and how Reconstruction might have affected original understandings. This is a case, after all, not simply about the authority to structure state and local governments, but about claims of racial discrimination in voting. If Section 2 of the Fifteenth Amendment speaks to any issue at all, it certainly speaks to this one. And yet, here's what we get from the Court:

Outside the strictures of the Supremacy Clause, States retain broad autonomy in structuring their governments and pursuing legislative objectives. Indeed, the Constitution provides that all powers not specifically granted to the Federal Government are reserved to the States or citizens. ${ }^{107}$

For support, Chief Justice Roberts cites the Tenth Amendment. ${ }^{108}$ Full stop. But the obvious question is, at the very least, whether the Reconstruction Amendments "may be treated as a gloss" 109 on the Tenth Amendment? The Court's decision in Shelby County, as evidenced by its reliance on the Tenth Amendment in support of its reserved powers argument, rests on the assumption that the Reconstruction Amendments did not change our understanding of "our federalism" in any meaningful way. The Court's assumption in Shelby County begs the question about the purposes of the Fourteenth and Fifteenth Amendments. One might think that the reserved powers of the states were altered by the grant of power to Congress in Section

achieves none of the beneficial goals that the Court claims for it."). But see Lynn A. Baker \& Ernest A. Young, Federalism and the Double Standard of Judicial Review, 51 DUKE L.J. 75, 136-39 (2001).

107 Shelby Cnty. v. Holder, 133 S. Ct. 2612, 2623 (2013).

108 See id. at 2623.

109 See Youngstown Sheet \& Tube Co. v. Sawyer, 343 U.S. 579, 611 (1952). 
5 of the Fourteenth Amendment and Section 2 of the Fifteenth. Put differently, the Court should produce an argument, at the very least, that the Fourteenth and Fifteenth Amendments did not alter the voting landscape, rather than simply trot out the Tenth Amendment as a trump card.

Instead, Chief Justice Roberts deploys two arguments we have seen many times before: first, that federalism is an unqualified good, as a preserver of liberty; and second, that this is the federalism balance as forged at the founding. More specifically, while conceding that Congress has "significant control over federal elections," the Court underscores that the states have "broad powers to determine the conditions under which the right of suffrage may be exercised."110 Notably, Reconstruction plays no role in the quest to identify and restore the original federalism line.

One response to the restoration project is to view it as incoherent. As Professor Tolson has argued, the quest to find and restore the supposed original federalism balance is "elusive,"111 "arbitrary,"112 and "nonexistent."113 A second response is to take issue with the Court's historiography and the way it has played a crucial role in obscuring the significance of the Reconstruction Amendments. ${ }^{114}$ At the very least, the Court has emphasized certain parts of our federalism history over others. If this is true, the recent federalism revival, and the way the Court portrays the history of our federalism from the founding and through the Civil War, is in line with the Court's past practice of downplaying or ignoring the importance of Reconstruction to federalism. Shelby County is consistent with that past practice.

To be sure, the Court has discussed federalism principles at great length prior to Shelby County. ${ }^{115}$ One can certainly dispute

110 Shelby Cnty., 133 S. Ct. at 2623 (citing Carrington v. Rash, 380 U.S. 89, 91 (1965)) (quotations omitted).

111 Tolson, supra note 12 , at 1200 .

112 Id.

113 Id. at 1253

114 See Pamela Brandwein, Reconstructing Reconstruction: The Supreme Court and the Production of Historical Truth (1999); Norman W. Spaulding, Constitution As Countermonument: Federalism, Reconstruction, and the Problem of Collective Memory, 103 CoLUM. L. REv. 1992 (2003). For the classic account of historical memory and how we remember the Civil War and Reconstruction era, see DAVID W. BLIGHT, RACE AND REUNION: THE CIVIL WAR IN AMERICAN MEMORY (2003).

115 See United States v. Morrison, 529 U.S. 598 (2000); City of Boerne v. Flores, 521 
the quality of this history. ${ }^{116}$ But far more important is the way in which the Court has considered the larger historical narrative of federalism. The justices themselves have played a critical role in creating and legitimizing a particular and partial version of constitutional history, particularly Reconstruction. Professor Norman Spaulding discusses this point, framed as a problem of collective memory, quite arrestingly. ${ }^{117}$ According to Spaulding, "[t]he historical consciousness of the federalism revival, the logic of its memory work, turns on a chillingly amnesic reproduction of antebellum conceptions of state sovereignty."118 In other words, we remember our federalism as forged at the founding while discounting-or rather forgetting, or refusing to remember-the Civil War and Reconstruction, that very moment in history when the country almost cracked at the fissures of its federalism failure. Chief Justice Roberts's citation to the Tenth Amendment is an attempt to lay "claim to the ostensibly unimpeachable authority of returning to first principles and founding intentions." 119 The return to first principles is as much an attempt to cleanse founding-era federalism as it is to re-remember, or remember differently, the Civil War and Reconstruction. "Our descent into a protracted, internecine war following secession was over nothing, after all, if not the fate of a particularly robust strain of federalism and the grave, anti-democratic injustices it insulated." 120 Even as the logic of federalism pulled the country apart along sectional lines, federalism's constitutional standing lost none of its luster.

U.S. 507 (1997); Lopez v. United States, 514 U.S. 549 (1995); Gregory v. Ashcroft, 501 U.S. 452 (1991).

116 See, e.g., Alden v. Maine, 527 U.S. 706, 762-808, 814 (1999) (Souter, J., dissenting) (describing Court's view of state sovereign immunity as "true neither to history nor to the structure of the Constitution"); Seminole Tribe v. Florida, 517 U.S. 44, 95-99 (1996) (Stevens, J., dissenting). In reference to the Court's discussion of the historical record in City of Boerne, for example, see Ruth Colker, The Supreme Court's Historical Errors in City of Boerne v. Flores, 43 B.C. L. REv. 783 (2002); Michael W. McConnell, Institutions and Interpretation: A Critique of City of Boerne v. Flores, 111 HARV. L. REv. 153, 174-83 (1997). Compare also the Court's suggestion that Section 1 of the Fourteenth Amendment was redrafted in order to assuage federalism concerns, City of Boerne, 521 U.S. at 520-24, with Eric Foner's argument that this section was redrafted in order to allow the judiciary to protect rights at times when Congress did not, ERIC FONER, RECONSTRUCTION: AMERICA'S UNFINISHED REVOLUTION, 1863-1877 228-80 (1988)
117 Spaulding, supra note 114.
118 Id. at 2015
119 Id.
$120 \quad I d$. at 2016. 
This move allows us to understand the concept of federalism as conditioning the Reconstruction project. Reconstruction could not radically alter the foundational commitment to federalism; it changed nothing. Reconstruction needed to take a backseat to first principles. In time, it might even disappear from view.

This narrative of Reconstruction began as soon as the Supreme Court considered the landmark achievement of the period in the Slaughterhouse Cases. ${ }^{121}$ Remember the question: how did Reconstruction alter the original federalism calculus? The Court offers its answer in the following passage:

Was it the purpose of the Fourteenth Amendment, by the simple declaration that "no State shall make or enforce any law which shall abridge the privileges or immunities of citizens of the United States," to transfer the security and protection of all the civil rights which we have mentioned, from the States to the Federal government?

And where it is declared that Congress shall have the power to enforce that article, was it intended to bring within the power of Congress the entire domain of civil rights heretofore belonging exclusively to the States?122

To ask this question, of course, is to answer it. Such was the memory of federalism as established by the founding generation and understood by the Court in 1873 .

The Roberts Court is clearly channeling this argument, and this memory of Reconstruction, in Shelby County. But this memory emphasizes only part of our federalism history. In reference to the Equal Protection Clause, the Slaughterhouse Cases underscored that Reconstruction had assigned a particular role for the Court. According to Justice Miller:

In the light of the history of these amendments, and the pervading purpose of them, which we have already discussed, it is not difficult to give a meaning to [the Equal Protection] clause. The existence of laws in the States where the newly emancipated negroes resided, which discriminated with gross injustice and hardship

\footnotetext{
121 The Slaughterhouse Cases, 83 U.S. (16 Wall.) 36 (1873).

122 Id. at 77.
} 
against them as a class, was the evil to be remedied by this clause, and by it such laws are forbidden. ${ }^{123}$

This language is indicative of a Court willing to protect the rights of the freedmen even if unwilling to become a censor of state laws when it came to the general question of rights enforcement. The argument should apply with considerable force to cases like Shelby County, when a claim of racial discrimination is supported by the explicit protections constitutionalized by the Fifteenth Amendment.

In due course, however, the Supreme Court, and the nation in general, lost its appetite to take on the racist elements of its society. Scholars disagree whether Slaughterhouse signals this shift, or United States $v$. Cruikshank, ${ }^{124}$ or the Civil Rights Cases, ${ }^{125}$ or even Plessy v. Ferguson. ${ }^{126}$ We do not need to resolve this scholarly argument here. ${ }^{127}$ For our purposes, it is important to note only that a scholarly debate exists, ${ }^{128}$ and that the Supreme Court is not willing to acknowledge it.

123 Id. at 81

12492 U.S. 542 (1875).

125109 U.S. 3 (1883).

126163 U.S. 537 (1896); see PAMELA BRANDWEIN, RETHINKING THE JUDICIAL SETTLEMENT OF RECONSTRUCTION (2011).

${ }^{127}$ A subsequent project will tackle these questions head on. For now, we simply note that, whatever one thinks of when the judicial retreat from Reconstruction began, the Chase and Waite Courts undermined important anti-terrorist laws that protected democracy and majority rule and allowed for the forging of multi-racial coalitions. See, e.g., ERIC FONER, supra note 116, at 279, 342-44, 425-44 (1988); VERNON LANE WhaRTon, The Negro In MississipPI 1865-1890 181-206 (1984); Michael Kent Curtis, The Klan, The Congress, and The Court: Congressional Enforcement of the Fourteenth and Fifteenth Amendments and the State Action Syllogism: A Brief Historical Overview, 11 U. PA. J. CONST. L. 1381 (2009). These early decisions - e.g., The Slaughter-House Cases, 83 U.S. (16 Wall.) 36 (1873); United States v. Cruikshank, 92 U.S. 542 (1875); United States v. Reese, 92 U.S. 214 (1875); United States v. Harris, 106 U.S. 629 (1882) - according to Michael Kent Curtis, "helped a minority that used terrorist tactics, force, and fraud displace democracy and majority rule." Id. at 1383 . The results, he writes, "were especially awful for Americans of African descent." Id.

128 See, e.g., BRANDWEIN, supra note 114; FONER, supra note 116, at 529-31 (1988); ROBERT J. KaCZOROWSKI, THE POLITICS OF JUdICIAL INTERPRETATION: THE FEDERAL CourTs, DePartment of Justice AND Civil Rights, 1866-1876 (1985); Michael Les BENEDICT, Preserving the Constitution: The Conservative Basis of Radical Reconstruction, in Preserving THE Constitution: Essays ON POLITICS AND THE Constitution IN THE RECONSTRUCTION ERA 3-22 (2006); Michael Les Benedict, Preserving Federalism: Reconstruction and the Waite Court, 1978 SUP. CT. REV. 39 (1978); Robert J. Kaczorowski, Revolutionary Constitutionalism in the Era of the Civil War and Reconstruction, 61 N.Y.U. L. REV. 863, 891 (1986) (arguing that the critical question for federalism after the war "was which government, the national or the state, possessed the primary power and responsibility for securing citizens' fundamental 
The Court's apparent refusal to take cognizance of the historical debate surrounding Reconstruction is worth noting for a more important reason. The ebbs and flows of Reconstruction history, and the role this history plays on judicial decisionmaking, offers an important example of why the content of our constitutional history must be understood as "a matter of normative value." 129 In the words of Richard Primus:

We want the history to be one thing rather than another, to illustrate certain principles or ideals that make it worth being connected to. The normative stakes in choosing which history to deploy in constitutional discourse thus transcend proximate issues about how particular bits of history will bear on cases, because the struggle over the content of constitutional history is only partly a struggle about how those cases will be decided. It is also a struggle about a more general sense of the meaning of American constitutional history. ${ }^{130}$

This is an argument for constitutional history as a judicial creation, bound by the biases, ideology, and particular outcomes that the justices inevitably hold. To be sure, there are times when the justices simply make mistakes. This is how we choose to think of the way the federal courts often cited to works from the Dunning School, and particularly Claude Bowers' The Tragic $E r a,{ }^{131}$ which Eric Foner offers an as example of "the persistent white supremacist narrative of Reconstruction masquerading as proper history." 132 But more generally, the justices use history instrumentally, as a way to justify decisions reached on other

rights" and concluding that the power must lie with the national government); Robert $\mathrm{C}$. Post \& Reva B. Siegel, Equal Protection by Law: Federal Antidiscrimination Legislation After Morrison and Kimel, 110 YALE L.J. 441, 507 n. 290 (2000) ("Legal historians are divided in their assessment of this tumultuous period of constitutional development and the Court's performance in it."). For a brief overview of this literature, see Michael Les Benedict, Constitutional History and Constitutional Theory: Reflections on Ackerman, Reconstruction, and the Transformation of the American Constitution, 108 YALE L.J. 2011, 2028-35 (1999).

129 Richard A. Primus, Judicial Power and Mobilizable History, 65 MD. L. REV. 171, 194 (2006).

130 Id.

131 Claude G. Bowers, The Tragic Era: The Revolution AFTER LinColn (1929).

${ }^{132}$ Eric Foner, The Supreme Court and the History of Reconstruction-and ViceVersa, 112 ColuM. L. REV. 1585, 1594 (2012) (quoting BRUCE E. BAKER, WHAT RECONSTRUCTION MEANT: HISTORICAL MEMORY IN THE AMERICAN SOUTH 148 (2007)). 
grounds. ${ }^{133}$ This is one way of thinking about the affirmative action cases, the school desegregation cases, and the vote dilution cases, which offer what Foner calls "a cramped and ahistorical understanding of the Fourteenth Amendment and the era of Reconstruction." 134

The reality is that people of color have fared worse at the state level than at the national level. It bears asking why the federal government has provided a far friendlier forum for communities of color to protect themselves and their interests. Whatever the answer, it would not be implausible to view Reconstruction as a moment when we reset the federalism calculus, and placed the federal government ahead of the states. This is an argument that one particular reading of Slaughterhouse appeared to dismiss. But then, hasn't history overruled Slaughterhouse?

Another way to think about this issue is by thinking about race legislation as historical anomalies, which altered the federalist balance but only, and perhaps intentionally, for a time and for particular historical reasons. Think here of the Freedmen's Bureau, which was established on a temporary basis, ${ }^{135}$ or the Voting Rights Act, whose special provisions were set to expire within five years of enactment, ${ }^{136}$ or even Justice O'Connor's opinion for the Court in Grutter v. Bollinger, which set a twenty-five year timeline on the use of race in admissions. ${ }^{137}$ Think also, more generally, of the Civil Rights Cases, when the Court infamously explained:

When a man has emerged from slavery, and by the aid of beneficent legislation has shaken off the inseparable concomitants of that state, there must be some stage in the progress of his elevation when he takes the rank of a mere citizen, and ceases to be the special favorite of the laws, and when his rights as a citizen, or a man, are to be

\footnotetext{
133 Id. at 1604 .

134 Id. at 1600.

135 See An Act to Establish a Bureau for the Relief of Freedmen and Refugees $\S 1,13$ Stat 507, 507 (Mar 3, 1865).

136 Voting Rights Act of 1965, P.L. 89-110, 79 Stat. 437.

137539 U.S. 306,342 (2003).
} 
protected in the ordinary modes by which other men's rights are protected. ${ }^{138}$

The use of race by state actors is to treat people of color not as "mere citizen[s]" but as the "special favorite[s] of the laws."139 There is much irony in this argument. Prior to the Civil War, nobody would argue that people of color in the United States were the special favorites of the laws; in fact, they were quite the opposite. The War was fought over precisely that principle, as the country sought to reset constitutional understandings about racial equality and the right of citizens to own human beings. The Civil Rights Cases simply beg the question: what exactly did Reconstruction do? How did it affect the original federalism calculus? And specifically in reference to the rights of the very citizens for which the War was fought, how did Reconstruction alter the balance of power between the states and the national government to protect the rights of citizens of color?

But more pertinently, it is worth asking why our commitment to a certain type of racial equality-what some might call true racial equality-often seems to manifest itself as a temporally-bound project. The impatience with the long slog towards racial equality or, to be more precise, the lack of toleration for how the quest for racial equality impairs other types of constitutional values, is a recurring theme in our constitutional history. These are the Civil Rights Cases, the Freedmen's Bureau, the VRA, Grutter, and Shelby County. In other words, even if we assume that Reconstruction and the Civil Rights Movement relocated the federalism line in favor of the federal government as against the states, and if the federal government gained more power at the expense of the states because doing so was necessary to achieve racial equality, whatever power the federal government gained was only temporary. That is, one cannot assume any fixity with federalism and one cannot assume linearity with racial equality. Indeed, at least with respect to racial equality, its status seems to be historically contingent. ${ }^{140}$ This is the lesson of the Civil Rights Cases, Grutter, and Shelby County.

\footnotetext{
138109 U.S. 3, 25 (1883).

139 Id.

140 See Louis Michael Seidman, Depoliticizing Federalism, 35 HARV. J.L. \& PUB.
} 
It may very well be the case that we as a nation have never been full-throated nationalists and it is certainly the case that we as a nation have never subscribed to racial equality $u b e r$ alles as a constitutional principle. Nevertheless, even granting these points, it does not follow that Reconstruction and the Reconstruction Amendments contributed nothing to federalism. The modern Supreme Court has yet to wrestle with the history of Reconstruction or to offer its account of the relationship among race, the Reconstruction Amendments, and federalism. Maybe the Reconstruction Amendments do not add much to the federalism debate. Maybe the federalism balance forged at the Founding was the proper balance, though such a conclusion would take a very narrow view of what Reconstruction sought to accomplish. Regardless of the answer to the inquiry about the relationship between federalism and Reconstruction, these questions were front and center in Shelby County and they deserved to be addressed. Given how race has affected our understanding of federalism from the Founding, through Reconstruction, and through the Civil Rights era, the Court's analysis in Shelby County is, at the very least, incomplete. Moreover, given how critical federalism is to the Court's decision in Shelby County, the failure to wrestle with these admittedly difficult questions weakens the Court's analysis and makes the federalism project less compelling.

\section{RACE AND FEDERALISM UP AND DOWN}

Return now to the empirical question about the utility of federalism that we left open in the last Part. In this Part we want to introduce a consideration that has not been central to the modern federalism debate: whether federalism enhances the liberty of people of color. Chief Justice Roberts's desire in Shelby

POL'Y 121, 122 (2012) ("The argument about federalism is, or at least should be, deeply contextual, and it is political to the core. In different times and places, federalism has differing relationships with substantive justice, and, in all times and all places, people disagree about what counts as substantive justice."); see also Edward A. Purcell, Jr., Evolving Understandings of American Federalism: Some Shifting Parameters, 50 N.Y.L. SCH. L. REV. 635, 697 (2005-06):

This essay has suggested some of the ways in which America federalism and our basic assumptions about its nature have changed over the centuries. When we study the federal system, it suggests, we are examining an evolving phenomenon, and we are doing so on the basis of concepts, assumptions and criteria that are themselves changing. 
County to return the federalism balance to what it was not only prior to the intervention of the 1965 Voting Rights Act, but also prior to the Nineteenth Century and the Civil War Amendments, could be sensible under the right set of assumptions. One of the supposed great virtues of (our) federalism is that it enhances liberty because it facilitates the ability of national or ethnocultural minorities to rule by becoming local majorities. ${ }^{141}$ From this perspective, defending federalism is defending the liberty of local minorities against national majorities. But the question that anti-nationalists, in particular the anti-nationalists on the Court, often fail to ask is, liberty for whom? The critical inquiry for modern proponents of federalism is whether federalism works for racial minorities in the way that federalist theorists purport. Put differently, states' rights theorists ${ }^{142}$ never pause to ask whether the states are truly in competition with the federal government for protecting the rights of racial minorities. They never pause to ask whether federalism is good for people of color.

Though past need not be prologue, the concept of states' rights has, to put the point mildly, a sordid past in American history. ${ }^{143}$ Federalism has not generally been viewed as an institutional arrangement that enhances the liberty of racial minorities in the United States; in fact, it has been viewed as doing the opposite. ${ }^{144}$ The way that racism has been deployed in the name of federalism is a problem for federalism's advocates. ${ }^{145}$ Whether fair or not, states' rights in the United

141 See The Federalist No. 10 (James Madison).

142 We use the term descriptively and not at all pejoratively.

${ }^{43}$ See, e.g., Paul Finkelman, States' Rights, Southern Hypocrisy, and the Crisis of the Union, 45 AKRoN L. REv. 449 (2012); Larry Yackle, Competitive Federalism: Five Clarifying Questions, 94 B.U. L. REV. 1403 (2014).

144 See Douglas Laycock, Protecting Liberty in a Federal System: The US Experience, in PATTERNS OF REGIONALISM AND FEDERALISM: LESSONS FOR THE UK 119, 119-47 (Jörg Fedtke \& Basil S. Markesinis, eds. 2006); Mark DeWolfe Howe, Federalism and Civil Rights, 77 Proc. MASS. HIST. Soc'Y 15, 18 (1965) (arguing that "the old commitment to national silence and national disability still serves to make American federalism a significant impediment to the fulfillment of civil rights"); S. G. F. Spackman, American Federalism and the Civil Rights Act of 1875, 10 J.AM. STUD. 313, 328 (1976) ("The federal system has always been as stout barrier to racial justice as American attitudes and political demands.").

145 William H. Riker, FEDERALism: ORigin, OpERation, Significance 152, 155 (1964) (explaining that "[t]he main beneficiary [of federalism] throughout American history has been the Southern Whites, who have been given the freedom to oppress Negroes .... . [I]f in the United States one approves of Southern white racists, then one should approve of American federalism."). Riker softened his earlier views in later 
States has generally been associated with racial inequality. ${ }^{146}$ Conversely, federal power has generally been associated with racial equality. ${ }^{147}$ From the perspective of citizens of color, liberty has in fact been delivered not by federalism but by nationalism. ${ }^{148}$ It thus would take a lot of chutzpah to curtail federal power, which is being deployed to protect liberty in an area where the states have engaged in notorious and rampant race discrimination, in the name of states' rights. But this is precisely what Chief Justice Roberts did in Shelby County.

Central to the Chief Justice's argument in Shelby County for recalibrating the balance between state and federal power is the premise that the states are no longer engaging in systematic racial discrimination of the type that gave rise to the 1965 Act. ${ }^{149}$ This argument prompted a dissenting response from Justice Ginsburg, who maintained that the states might go back to their old ways and use proxies that either directly or indirectly minimize the political power of racial minorities or indirectly do so. ${ }^{150}$ Additionally, Justice Ginsburg argued that in the last fifty years, if not since Reconstruction, the federal government has assumed the primary responsibility and has in fact done a better job of protecting the electoral rights of racial minorities. ${ }^{151}$ Thus, as between the states and the federal government, the federal government is the less risky option, the safer bet.

For both Roberts and Ginsburg, the federalism question (that is, how much reserved powers do the states have or should the states have as against the federal government in the voting domain) is a function of a predictive judgment: whether the states are likely to engage in racial discrimination in voting as they did before or whether we have we moved well beyond that era. If we think the states are likely to backtrack, we ought to

\footnotetext{
works. See William H. Riker, The Development of AMERICAN FEdERALiSM (1987).

146 See id. For a rejoinder as applied to modern note 25 , at 37-38.

147 Laycock, supra note 144

148 Id.

149 Shelby Cnty. v. Holder, 133 S. Ct. 2612, 2629 (2013) ("Regardless of how to look at the record, however, no one can fairly say that it shows anything approaching the 'pervasive,' 'flagrant,' 'widespread,' and 'rampant' discrimination that faced Congress in 1965 , and that clearly distinguished the covered jurisdictions from the rest of the Nation at that time.").

${ }_{150} \quad I d$. at 2651.
${ }_{151}$
$I d$. at 2652.
} 
favor the federal government; but if we think the states are reformed, we should return to them the reserved powers they presumably possessed at the Founding. Both justices used memorable analogies to make their respective points: Roberts that robust federal power is no longer necessary and Ginsburg that the states are likely to backtrack without federal supervision. ${ }^{152}$ During the oral arguments in Northwest Austin, Roberts characterized the argument that it is the VRA that is keeping the states from engaging in racial discrimination in voting to be as compelling as the old story that an "elephant whistle" explains the absence of elephants. That is, he continued, "I have this whistle to keep away the elephants. You know, well, that's silly. Well, there are no elephants, so it must work." 153 In her Shelby County dissent, Ginsburg retorted by characterizing the argument that the coverage formula is no longer necessary because states are not currently engaged in racial discrimination as "like throwing away your umbrella in a rainstorm because you are not getting wet." 154

Roberts and Ginsburg are undoubtedly engaged in an important debate. But in one critical respect, the battle between Roberts and Ginsburg and the sides that they represent is beside the point, if the point is about federalism. The federalism question should not be whether the states will or will not engage in discrimination if federal supervision is removed. The federalism question ought to be whether the states will compete with the federal government for the allegiance of racial minorities. If one important and central argument in favor of federalism, and thus Shelby County, is that devolution of power enhances liberty by facilitating self-rule by national minorities or ethnocultural minorities, the question that Chief Justice Roberts and Justice Ginsburg should have been debating is whether removing central supervision will now better permit racial minorities-who are also ethnocultural minorities-to engage in self-rule. Instead of asking whether the states are widely or systematically discriminating against their citizens of color, the Court should have asked how well are the states

152 See Transcript of Oral Argument at 28, N.W. Austin Mun. Util. Dist. No. One v. Holder, 557 U.S. 193 (2009) (No. 08-322) (Elephant); Shelby Cnty., 133 S. Ct. at 2650.

${ }_{153}$ Transcript of Oral Argument at 28, N.W. Austin Mun. Util. Dist. No. One v. Holder, 557 U.S. 193 (2009) (No. 08-322).

154 Shelby Cnty., 133 S. Ct. at 2650. 
representing the interests of their citizens of color. What is the congruence between the policy preferences of citizens of color in Alabama, Texas, North Carolina, Georgia, etc., and the legislative outcome of their respective states? How well are these citizens represented by their states? This should be the question for federalism in this context.

If one is inclined to be generous, one can view Chief Justice Roberts's opinion in Shelby County as deeply generative. Roberts wants a restart on race, history, and federalism. Recall here his point in Shelby County that history did not end in $1965 . .^{155} \mathrm{We}$ have argued elsewhere Roberts used Shelby County to redeem the states. ${ }^{156}$ But the states are not all that Roberts wants to redeem; he also wants to redeem federalism from its sordid past, a laudable goal. The anti-nationalists aim to change the states' rights narrative so that the idea of states' rights is no longer synonymous with racial discrimination. Recall also Chief Justice Roberts's claim in Shelby County that the South has changed, or at the very least it does not differ much, if at all, from the North. ${ }^{157}$

The redemption of federalism is an intriguing and worthwhile project. It would be salutary and productive to get beyond the states' rights as racism meme. And it is not fair to federalism's advocates to constantly tar them with the putridity of the past. But redemption is not cheap. If federalism is to be redeemed, federalism must work for people of color as well. And if federalism is to "work" for people of color, it is not enough for proponents of federalism to show that the states will no longer engage in rampant racial discrimination.

Our task here is to introduce a distinction between an argument for states' rights premised on the idea that the states (or many of them) are no longer engaging in racial discrimination and an argument for states' rights in which the states are actively representing the interests of their citizens of color. From our perspective, the argument for federalism cannot be premised on the idea that the states are no longer discriminating against racial minorities. It is not sufficient to simply say that the states are indifferent. The Court should not interpret the Constitution in a way that would disempower the

155 Id. at 2628.

156 See Charles and Fuentes-Rohwer, supra note 13, at 514-24.

157 Shelby Cnty., 133 S. Ct. at 2625. 
federal government, which is the governmental entity that best represents the interests of citizens of color, and leave citizens of color to the indifference of the states. Indifference is not an argument for federalism. Federalism promises better representation, at least as compared to representation from the center or as compared to a unitary system. Our point is that the promise of better representation or the promise of competition for representation ought to be extended to people of color. ${ }^{158}$

This is why the argument between Roberts and Ginsburg is beside the point. The states' side of federalism must do what federalism theory expects devolution and decentralization to do. Federalism must defend and protect racial representation. The states must rival the federal government for the affections of racial minorities. It is not enough that federalism is not bad for people of color; federalism must be good for people of color. This is the task of federalism.

Once the federalism argument is properly framed, we can see the potential for Shelby County to be deeply generative. If federalism protects liberty, it is only fair to ask, liberty for whom? By putting the federalism question on the table, we can ask seriously and non-cynically whether federalism can do the work of racial representation and thus further racial equality. ${ }^{159}$ Shelby County's reintroduction of federalism into the debate about whether the states or the federal government best protects people of color imposes a new burden on the states that they did not until now have to bear. To this point, the states had to bear the burden of non-discrimination, and had to do so at least since the passage of the Reconstruction Amendments. Moving forward, they must now bear the burden of actively and effectively representing the liberty interests of their citizens of color. This is the expectation for federalism post-Shelby County. The redemption project is worth taking seriously. It promises to be generative and promises to take us beyond tired recriminations.

Now consider federalism from a different vantage point, not that of redeeming the states, but that of progressives concerned

158 Professor Nicholas Stephanopoulos has recently argued that the policy preferences of African Americans are underrepresented at both the federal and state levels. See Nicholas Stephanopoulos, Political Powerlessness (forthcoming NYU Law Review); see also Bertrall L. Ross II \& Su Li, Measuring Political Power: Suspect Class Determinations and the Poor (forthcoming Cal. L. Rev.).

159 For an argument that it can, see Somin, supra note 25. 
about the redemption of political-racial, gender, sexual, etc.minorities. ${ }^{160}$ For example, Professor Kathleen Sullivan argued almost a decade ago that "champions of liberal causes might need to rethink any reflexive recoil from" the federalism revolution wrought by the Rehnquist Court because it "might well contain seeds of a constitutional concept of social fluidity that can help to realize progressive as well as conservative ideals."161 Professor Sullivan implicitly reasoned that the association of progressive equality with nationalism was historically contingent and always subject to a different political reality. The valence of federalism changed when the politics changed. Thus she noted:

But once the Republican Party obtained simultaneous control of the White House, House, and Senate for the first time since 1954, local and state initiatives began to do more than federal programs to advance progressive social ends. Gay weddings took place through the executive action of Mayor Gavin Newsom of San Francisco and the state constitutional interpretation of Chief Justice Margaret Marshall writing for the Massachusetts Supreme Judicial Court. Oregon pioneered physician-assisted suicide while California experimented with allowing severely ill patients to use marijuana medicinally. Suddenly states' rights were no longer just for segregationist southerners. Conversely, conservatives have sought to transform entrenched control of the federal government into nationwide social restrictions-from regulating late-term abortion to limiting stem-cell research-that were once unthinkable at the federal level. ${ }^{162}$

She concludes that federalism can serve as a handmaiden for social equality and need not be in service of inequality. Similarly, Professor Gerken has forcefully argued that:

[I] $\mathrm{t}$ is a mistake to equate federalism's past with its future. State and local governments have become sites of empowerment for racial minorities and dissenters, the

\footnotetext{
160 See, e.g., Gerken, supra note 25; Sullivan, supra note 17.

161 Sullivan, supra note 17 , at 801.

162 Id. at $810-11$.
} 
groups that progressives believe have the most to fear from decentralization. In fact, racial minorities and dissenters can wield more electoral power at the local level than they do at the national. And while minorities cannot dictate policy outcomes at the national level, they can rule at the state and local level. Racial minorities and dissenters are using that electoral muscle to protect themselves from marginalization and promote their own agendas. ${ }^{163}$

Professor Gerken went on to note that "[f]ederalism and localism ... depend on-even glory in - the idea of minority rule." 164 She reminded us "what we have today is not your father's federalism." 165

These are strong arguments in favor of reconceptualizing federalism as capable of redeeming people and not states. We are certainly open to this possibility. But at least in the context of voting, the early returns across the states are not very promising. We can look to North Carolina, or Indiana, or Wisconsin, or Texas, to name a few states. Following Shelby County, each of these states moved to change their electoral laws in ways that were inimical to the electoral liberty interests of the voters of color in their states. ${ }^{166}$ These states are not engaged in protecting the rights of people of color, far from it. If we are going to empower the states as the primary guarantors of racial liberty, we must ensure that they are up to the task. That task is not about ascertaining whether the states are or are not engaged in racial discrimination. If we are engaged in that debate we are not engaged in the task that modernity expects of federalism. The question for federalism in the $21^{\text {st }}$ century is whether the states will compete with the federal government to represent their citizens of color in the same way that they ostensibly compete to represent their white citizens. The

\footnotetext{
163 Gerken, supra note 25.

$164 I d$.

$165 I d$.

166 See, e.g., Thomas B. Edsall, The Decline of Black Power in the South, N.Y. TIMES (July 10, 2013), http://opinionator.blogs.nytimes.com/2013/07/10/the-decline-of-blackpower-in-the-south/, archived at http:/perma.cc/EM28-DY3V; Steven Yaccino \& Lizette Alvarez, New G.O.P. Bid to Limit Voting in Swing States, N.Y. TIMEs (Mar. 30, 2014), available at http://www.nytimes.com/2014/03/30/us/new-gop-bid-to-limit-voting-in-swingstates.html, archived at http://perma.cc/3ZZ2-2PAL.
} 
challenge for the Court and modern proponents of federalism is to encourage the states to take up the role that modern federalism has envisioned for them, or else neo-federalism should simply be dismissed like the old federalism.

Relatedly, if federalism is thought to further decentralization-and decentralization is thought to enhance liberty and self-government-it is not clear why the VRA is not viewed as an ally of the federalism project. In the context of voting, the Voting Rights Act is the implementation of decentralization. Sections 2, 4, and 5 of the VRA compelled devolution of power, under the right circumstances, to local entities. The VRA created majority-minority districts, which assured that voters of color constituted a majority of voters in a least some electoral jurisdictions. The VRA operated at the county-level, the school board level, the commission level, and the city council level, inter alia. It forced political elites at the state level to consult with sub-state political elites. It empowered local minorities. Admittedly, the local minorities empowered by the VRA were racial minorities, but they were minorities nonetheless. It is hard to conceive of a structural scheme that empowered local minorities, in this case racial minorities, more than the VRA.

The puzzling question is, why is the VRA is not viewed as federalism-reinforcing? Why is it that when we think of states' rights, we do not think of the large majority of citizens of color within those states? Even more intriguingly, what will happen to states' rights when it unequivocally means minority empowerment? Our aim in this Part was to put those questions squarely on the table.

\section{CONCLUSION}

We are in the midst of an important public conversation about race, federalism, and voting rights. It is a conversation about history, doctrine, and politics. The optimistic read on Shelby County is that it is forcing us to have a conversation 
about the optimal structural and political arrangements for best representing the citizens of our polity, in particular citizens of color. Perhaps closer to reality, Shelby County is a legerdemain that is completely uninterested in representation and is simply intent on redrawing the federalism line as reset fifty years before. If so, the federalism enterprise ought to be subjected to critical inquiry. We must inquire why the project of racial equality must take a back seat to the federalism project. We must inquire why the Court is disempowering Congress as the political body that has best protected the electoral interests of people of color and empowering the states, the sovereigns that have historically shown a lesser inclination to extend these crucial protections. If federalism is to be redeemed, it must first prove that the states will actively compete with the federal government to protect the rights of racial minorities. Though history has not been kind to federalism, we ought to keep an open mind. However, in the immortal words of Ronald Reagan, we should trust, but verify. 